\title{
Penerapan Model Pembelajaran Problem Centered Learning (PCL) Pada Kompetensi Melakukan Penyimpanan Barang Persediaan untuk Meningkatkan Hasil Belajar dan Aktifitas Belajar
}

\author{
Rachmad Andriani \\ SMK Negeri 3 Blitar \\ Email: rachmadandriani@gmail.com
}

\begin{abstract}
Abstrak: Hasil penelitian yang diperoleh menunjukan peningkatan hasil belajar siswa untuk setiap siklusnya. Hasil belajar pada siklus I sebesar 63,2 (kompeten dengan predikat cukup), pada siklus II sebesar 75,5 (kompeten dengan predikat baik), dan pada siklus III sebesar 87,3 (kompeten dengan predikat baik). Hasil rata-rata aktivitas siswa mengalami kenaikan untuk setiap siklusnya, rinciannnya adalah siklus I 67,61\% (katagori tinggi), meningkat pada siklus II menjadi 77,56\% (katagori sangat tinggi ), meningkat pada Siklus III menjadi 91,48\% (kategori sangat tinggi). Kesan dan tanggapan siswa melalui angket menyatakan bahwa dengan menerapkan model Problem Centered Learning (PCL) pada kompetensi dasar melakukan

Tersedia Online di

http://journal.unublitar.ac.id/pendidikan/index .php/Riset_Konseptual

Sejarah Artikel

Diterima pada : 29-10-2021

Disetuji pada : 29-10-2021

Dipublikasikan pada : 31-10-2021

\section{Kata Kunci:}

Problem Centered Learning, Kompetensi, Hasil Belajar,Aktivitas Belajar

DOI:

http://doi.org/10.28926/riset_konseptual.v5i4.440 penyimpanan barang persediaan sangat menyenangkan bagi siswa, dimana siswa bisa bertukar pikiran dengan teman mengenai materi yang disampaikan dan suasana pada saat pembelajaran berlangsung tidak begitu tegang dan lebih santai. Kesan dan tanggapan guru mata pelajaran melalui wawancara menyatakan bahwa dengan menerapkan model PCL membuat kondisi kelas menjadi lebih aktif, siswa menjadi berani dalam mengungkapkan pendapatnya.
\end{abstract}

\section{PENDAHULUAN}

Pengelolaan Usaha Produk tataboga adalah pelajaran yang membekali siswa untuk berwirausaha. Hal ini diharapkan sebagai penyelesaian masalah pengangguran dengan membuka lapangan kerja baru yang berperan mengatasi masalah pengangguran. Banyak lulusan SMK lebih memilih menjadi tenaga kerja pada pekerjaan formal yang ada dibanding dengan mengaplikasikan kemampuan dan keterampilan yang dimilikinya untuk berwirausaha. Hal ini disebabkan kurangnya motivasi siswa dalam berwirausaha yang disebabkan kurangnya faktor- faktor motivasi yang dimiliki siswa seperti yang diungkapkan Sanjaya (2006) yaitu: (1) minat, (2) rasa percaya diri, (3) kepemimpinan, (4) berorientasi ke masa depan, (5) berorientasi tugas dan hasil serta (6) keberanian mengambil resiko untuk berwirausaha.

Kurangnya minat banyak disebabkan karena memulai suatu usaha dirasakan terlalu berat dibandingkan bekerja pada perusahaan atau pekerjaan formal lainnya. Persaingan di dunia usaha juga menjadikan siswa lulusan SMK merasa kurang percaya diri, kurang termotivasi untuk membuka usaha baru, sehingga takut adanya bayang-bayang kegagalan yang akan dihadapai di kemudian hari. Pembelajaran yang menerapkan pendekatan Problem Centered Learning merupakan suatu pembelajaran yang memberikan kesempatan bagi siswa agar melakukan aktivitas belajar yang berpotensi sehingga membuatnya berpartisipasi dalam belajar. Pendekatan 
pembelajaran ini mula-mula dikembangkan pada tahun 1986 oleh Cobb di sekolah dasar dan pada saat itu pendekatan pembelajaran ini disebut Problem-Centered Classroom. Kemudian pada awal tahun 90-an, Wheatley mengembangkan pendekatan pembelajaran ini di sekolah menengah dan disebut sebagai ProblemCentered Learning (Hafriani:2004).

Menurut Suwardi (2009) membagi metode PCL menjadi 3 komponen, yaitu: mengerjakan tugas, kegiatan kelompok dan berbagi (sharing). Secara rinci dapat dijelaskan (1) Langkah pertama: Menyiapkan kelas agar guru dapat menugaskan siswa untuk mengerjakan tugas yang dapat membuat siswa memecahkan masalah. (2) Langkah kedua: Membagi siswa dalam kelompok-kelompok kecil agar siswa dapat melakukan kolaborasi dalam aktivitas kelompok. (3) Langkah ketiga: Menyatukan semua siswa dalam diskusi kelas. Peran guru dalam diskusi ini hanyalah sebagai fasilitator dan setiap usaha dibuat untuk bersifat menilai tetapi hanya bersifat mendorong. Inti dari aktivitas pendekatan PCL adalah agar siswa dapat melakukan negosiasi dengan dirinya sendiri, siswa dengan siswa dan siswa dengan guru. Wheatley (2001) dalam pendekatan PCL, proses belajar terjadi ketika siswa mengkonstruksi pemahaman untuk pengalaman mereka, dan siswa bertindak serta berinteraksi dengan kelompoknya, sehingga mereka secara aktif mencoba untuk menyelesaikan permasalahan yang dihadapi dalam aktivitas yang berguna.

Proses pembelajaran di sekolah pada intinya melibatkan dua pihak yang saling berinteraksi, yaitu guru yang melaksanakan tugas mengajar dan siswa yang melaksanakan aktivitas belajar. Aktivitas belajar siswa berhubungan dengan seluruh rangkaian kegiatan siswa dalam melaksanakan belajar, sebagaimana dikemukakan Sudjana (2010) bahwa "Aktivitas belajar siswa merupakan keseluruhan peristiwa yang dilakukan dan dialami siswa selama mengikuti kegiatan pembelajaran di kelas". Aktivitas belajar siswa yang dimaksud adalah aktivitas jasmaniah, maupun aktivitas mental (psikis). Sesuai dengan pendapat Arsyad (2009) bahwa "aktivitas tidak hanya dimaksud aktivitas jasmani saja, melainkan aktivitas rohani”.

Beberapa jenis aktivitas belajar yang dikemukakan oleh Sardiman (2011) yang dalam hal ini mencakup aktivitas fisik dan mental yaitu: (a) Aktivitas Visual, (b) Aktivitas Oral, (c) Aktivitas Mendengar, (d) Aktivitas Menulis, (e) Aktivitas Motorik, (f) Aktivitas Menggambar, (g) Aktivitas Mental, (h) Aktivitas Emosi. Klasifikasi aktivitas seperti yang diuraikan di atas, menunjukkan bahwa aktivitas belajar itu cukup kompleks, bervariasi dan menuntut adanya kerjasama serta peran aktif pembelajar sehingga tujuan pembelajaran dapat tercapai.

\section{METODE}

Penelitian ini dilaksanakan dengan menggunakan metode penelitian tindakan kelas (Classroom Action Research), yang berusaha mengkaji dan merefleksikan secara kolaboratif suatu pendekatan pembelajaran dengan tujuan untuk meningkatkan proses dan prosedur pengajaran di kelas. Menurut Arikunto (2002:3) "Penelitian tindakan kelas (PTK) merupakan suatu pencermatan terhadap kegiatan belajar berupa sebuah tindakan yang sengaja dimunculkan dan terjadi dalam sebuah kelas secara bersama-sama". Model penelitian tindakan kelas ini dilaksanakan melalui empat kegiatan yang pelaksanaannya dilakukan secara berulang-ulang (siklus). Keempat kegiatan itu adalah perencanaan, tindakan, observasi, refleksi. Model penelitian tindakan kelas ini dilaksanakan melalui empat kegiatan yang pelaksanaannya dilakukan secara berulang-ulang (siklus). Keempat kegiatan itu adalah perencanaan, 
tindakan, observasi, refleksi. Desain penelitian merupakan kerangka, pola atau rancangan yang menggambarkan alur arah penelitian. Terdapat langkah-langkah atau tahap-tahap yang menunjukkan suatu urutan kerja dalam penelitian ini. Desain atau rancangan ini, peneliti dimungkinkan menentukan langkah-langkah secara terarah dan efisien, kemudian peneliti melakukan penelitian sesuai dengan desain penelitian yang akan digunakan.

Data yang dibutuhkan dalam penelitian tindakan kelas dengan model pembelajaran Problem Centered Learning (PCL) ini adalah Data awal tentang kondisi siswa diperlukan untuk melihat prestasi belajar sebelum diberikan tindakan agar penerapan model pembelajaran Problem Centered Leraning (PCL) tepat pada kelas yang akan diberi tindakan. Data diperoleh melalui observasi lapangan serta wawancara dengan guru mata pelajaran dan siswa. Data dasar diperoleh dari prestasi belajar yang ditampilkan siswa pada semester sebelumnya, diperoleh melalui analisa data ujian. Selama proses pemberian tindakan penerapan model pembelajaran Problem Centered Learning (PCL) data yang dibutuhkan adalah responrespon siswa selama mengikuti kompetensi dasar Melakukan Penyimpanan Barang Persediaan. Respon siswa diungkap melalui angket siswa, secara rinci dipaparkan pada bagian instrumen.

Instrumen yang digunakan dalam penelitian ini secara terperinci a. Instrumen tes hasil belajar. Soal tes terdiri dari 10 soal dan berbeda antara siklus pertama dan siklus yang selanjutnya, hal itu dimaksudkan agar tes berlangsung lebih objektif, selain itu tes dilakukan dua kali setiap siklusnya yaitu pre test dan post test. b. Lembar pedoman observasi. Lembar observasi ini sekaligus akan digunakan untuk mengukur hasil belajar pada ranah kognitif. c.Instrumen angket siswa. Angket siswa adalah untuk mengelompokan tanggapan siswa melalui pendapat atau komentar yang positif, negatif dan netral sehingga pada akhirnya diperoleh suatu kesimpulan bahwa tanggapan siswa mendapatkan respon positif atau negatif dari seluruh siswa.

\section{Teknik Pengolahan Data}

\section{Hasil Belajar Siswa}

Peningkatan hasil belajar pada materi melakukan penyimpanan barang diketahui dengan cara menghitung gain ternomalisasi $<\mathrm{g}>$. Menurut Hake (1998) gain ternomalisasi " $g$ " didefinisikan sebagai $<g>=$ gain/gain maksimum. Secara matematik gain ternomalisasi dapat ditulis sebagai berikut:

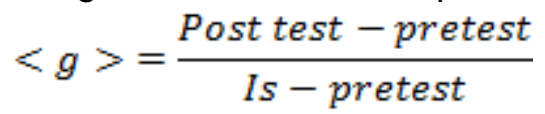

Dimana:

Is : Skor Maksimum Ideal

(Arikunto, 2011)

\section{Tanggapan Siswa}

Angket diberikan di akhir seluruh kegiatan pembelajaran. Angket tersebut merupakan angket menghitung jumlah siswa berdasarkan tanggapan dan membuat persentasenya dengan menggunakan rumus sebagai berikut:

$$
\begin{aligned}
& \mathrm{P}=\frac{\mathrm{Ir}}{\mathrm{J} s} \times 100 \% \text { Keterangan: } \\
& \mathrm{P}=\text { Persentase jawaban } \\
& \mathrm{Jr}=\text { Jumlah siswa dengan tanggapan sama } \\
& \mathrm{J} \mathrm{s}=\text { Jumlah seluruh siswa }
\end{aligned}
$$

(Suwardi: 2009) 


\section{Kegiatan Pembelajaran Siklus I \\ Perencanaan}

HASIL dan PEMBAHASAN

Rencana yang dibuat adalah keseluruhan proses pembelajaran yang disesuaikan dengan tujuan meningkatkan hasil belajar dan aktivitas belajar siswa. Tahapan pada siklus ini meliputi: a) Menetapkan model pembelajaran yang akan digunakan yaitu pembelajaran dengan model PCL. b) Menyusun Rencana Pelaksanaan Pembelajaran c) Menetapkan cara observasi, yaitu dengan menggunakan format observasi.

\section{Pelaksanaan}

Pelaksanaan pembelajaran siklus I dengan jumlah siswa yang hadir 22 orang. Pembelajaran pada siklus I ini membahas materi tentang pengertian penerimaan barang. Kegiatan pembelajaran siklus I ini diamati oleh observer. Kegiatan pembelajaran dengan PCL yang dilakukan secara garis besarnya tergambar sebagai berikut: a) Tahap orientasi. b) Tahap mengorganisasikan. c) Tahap membimbing. d) Mengembangkan dan menyajikan hasil karya. e) Menganalisis dan mengevaluasi proses pemecahan masalah.

\section{Hasil Belajar Siswa}

Hasil belajar aspek kognitif yang dimaksud pada penelitian ini dalah hasil belajar berupa nilai pre test dan nilai post test. Hasil dari pre test dan post test siklus pertama diperoleh sebagai berikut:

Tabel 1. Data Nilai Pre Test dan Post Test Siklus I

\begin{tabular}{|c|c|c|c|c|c|c|c|}
\hline \multirow{2}{*}{ No } & \multirow{2}{*}{ Nilai } & \multicolumn{2}{|c|}{ Pre Test } & \multicolumn{2}{|c|}{ Post Test } & \multirow{2}{*}{\multicolumn{2}{|c|}{ Keterangan }} \\
\hline & & Frekuensi & Persentase (\%) & Frekuensi & Persentase (\%) & & \\
\hline 1 & $90 \leq N_{k} \leq 100$ & & & 1 & 4,55 & \multirow{3}{*}{ Kompeten } & Amat Baik \\
\hline 2 & $80 \leq N_{k} \leq 89$ & & & 5 & 22,73 & & Baik \\
\hline 3 & $70 \leq N_{k} \leq 79$ & 2 & 9,09 & 12 & 54,55 & & Cukup \\
\hline \multirow[t]{4}{*}{4} & $0 \leq N_{k} \leq 69$ & 20 & 90,91 & 4 & 18,18 & \multicolumn{2}{|c|}{ Belum Kompeten } \\
\hline & Rata-Rata & \multicolumn{2}{|l|}{50,9} & \multicolumn{2}{|l|}{69,5} & & \\
\hline & N-Gain & \multicolumn{4}{|l|}{18,6} & & \\
\hline & Jumlah & 22 & 100 & 22 & 100 & & \\
\hline
\end{tabular}

Berdasarkan data hasil penelitian yang diperoleh dari siklus I, dapat ditunjukan bahwa nilai rata-rata pre test adalah 50,9 . Setelah menerapkan model pembelajaran PCL, maka nilai rata-rata ketuntasan hasil belajar aspek kognitif pada siklus I meningkat dengan $\mathrm{N}$-gain sebesar 18,6 . Rinciannya 1 orang $(4,55 \%)$ masuk kategori amat baik, 5 orang $(22,73 \%)$ masuk kategori baik, 12 orang $(54,55 \%)$ masuk kategori cukup, 4 orang $(18,18 \%)$ belum kompeten. Diagram peningkatan hasil belajar siklus I ditunjukan pada gambar 1

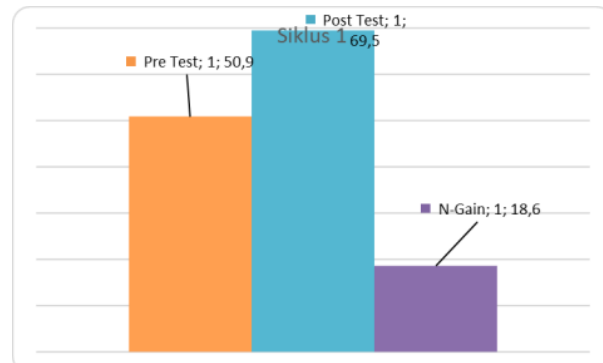


Gambar 1 menunjukan nilai rata-rata pre test yang diperoleh siswa sebelum dilakukan tindakan (pra tindakan) sebesar 50,9 dan setelah peneliti melakukan tindakan yaitu menerapkan pembelajaran PCL maka nilai rata-rata hasil belajar aspek kognitif siswa siklus I meningkat dengan N-gain sebesar 18,6 yaitu menjadi 69,5.

\section{Aktivitas Belajar Siswa}

Data hasil observasi terhadap aktifitas belajar siswa selama proses pembelajaran siklus 1 dapat dilihat pada table dibawah ini

Tabel 2 Hasil Pengamatan Aktivitas Belajar Siswa Siklus I

\begin{tabular}{|l|l|l|l|l|}
\hline No. & Skor & Frekuensi & Persentase (\%) & Kategori \\
\hline 1 & $<59$ & 6 & 27,27 & Kurang Sekali \\
\hline 2 & $60-69$ & 6 & 27,27 & Kurang \\
\hline 3 & $70-79$ & 6 & 27,27 & Cukup \\
\hline 4 & $80-89$ & 4 & 18,18 & Baik \\
\hline 5 & $90-100$ & & & Amat Baik \\
\hline
\end{tabular}

Berdasarkan data pada tabel di atas, aktivitas belajar siswa pada kegiatan belajar mengajar pada siklus pertama sudah termasuk kategori kurang dengan perolehan skor rata-rata sebesar 68,75 Hasil aktivitas belajar siswa pada siklus I sudah cukup baik sebagai awal pembelajaran.

\section{Refleksi}

Penulis melakukan refleksi setelah selesai melaksanakan observasi untuk menilai seberapa jauh keberhasilan penelitian. Hasil refleksi ini penulis peroleh dari evaluasi kegiatan bersama observer dan guru mata pelajaran mengenai kegiatan yang terjadi saat proses pembelajaran. Hal yang dapat disimpulkan dari pelaksanaan siklus I adalah sebagai berikut:

Hasil belajar siswa pada siklus I masih ada yang termasuk kategori belum kompeten yaitu sebanyak 4 orang ( $18,18 \%)$. Berdasarkan data, untuk memperbaiki keberhasilan yang telah dicapai pada siklus pertama maka pada pelaksanaan siklus kedua dibuat perencanaan guru harus menjelaskan kembali aturan dan teknis pembelajaran PCL ini sampai siswa benar-benar paham.

\section{Kegiatan Pembelajaran Siklus II \\ Perencanaan}

Perencanaan siklus II ini mengacu pada hasil refleksi siklus I yang telah dilakukan sebelumnya. Tahapan pada siklus ini meliputi: a) Menyusun Rencana Pelaksanaan Pembelajaran b) Membuat lembar observasi aktivitas siswa, yang digunakan sebagai alat observasi untuk melihat kegiatan siswa pada proses belajar mengajar.

\section{Pelaksanaan}

Pelaksanaan pembelajaran siklus II dengan jumlah siswa yang hadir 22 orang. Pembelajaran pada siklus II ini membahas materi tentang pengklasifikasian bahan makanan secara teliti, cermat dan rapih. Kegiatan pembelajaran siklus II ini diamati oleh observer.

\section{Hasil Belajar Siswa}

Hasil belajar yang dimaksud pada penelitian ini adalah hasil belajar berupa nilai pre test dan nilai post test. Hasil dari pre test dan post test siklus ke-2 adalah sebagai berikut: 
Tabel 3 Data Nilai Pre Test dan Post Test Siklus II

\begin{tabular}{|c|c|c|c|c|c|c|c|}
\hline \multirow{2}{*}{$\mathrm{No}$} & \multirow{2}{*}{ Nilai } & \multicolumn{2}{|l|}{ Pre Test } & \multicolumn{2}{|l|}{ Post Test } & \multirow{2}{*}{\multicolumn{2}{|c|}{ Keterangan }} \\
\hline & & Frekuensi & Persentase (\%) & Frekuensi & Persentase (\%) & & \\
\hline 1 & $90 \leq N_{k} \leq 100$ & & & 3 & 13,64 & \multirow{3}{*}{ Kompeten } & Amat Baik \\
\hline 2 & $80 \leq N_{k} \leq 89$ & 2 & 9,09 & 11 & 50 & & Baik \\
\hline 3 & $70 \leq N_{k} \leq 79$ & 5 & 22,73 & 8 & 36,36 & & Cukup \\
\hline \multirow[t]{4}{*}{4} & $0 \leq N_{k} \leq 69$ & 15 & 68,18 & & & \multicolumn{2}{|c|}{ Belum Kompeten } \\
\hline & Rata-Rata & \multicolumn{2}{|l|}{62,7} & \multicolumn{2}{|l|}{77,7} & & \\
\hline & N-Gain & \multicolumn{4}{|l|}{15} & & \\
\hline & Jumlah & 22 & 100 & 22 & 100 & & \\
\hline
\end{tabular}

Berdasarkan data hasil penelitian yang diperoleh dari siklus II, dapat ditunjukan bahwa nilai rata-rata pre test adalah 62,7 . Setelah menerapkan model pembelajaran PCL maka nilai rata-rata ketuntasan hasil belajar aspek kognitif siswa pada siklus II meningkat dengan $\mathrm{N}$-gain sebesar 15 dari nilai awal 62,7 yaitu menjadi 77,7. Rinciannya sebagai berikut: 3 orang (13,64\%) masuk kategori amat baik; 11 orang (50 $\%)$ masuk kategori baik, dan 8 orang (36,36\%)masuk kategori cukup. Diagram peningkatan hasil belajar siklus II ditunjukan pada gambar 2 .

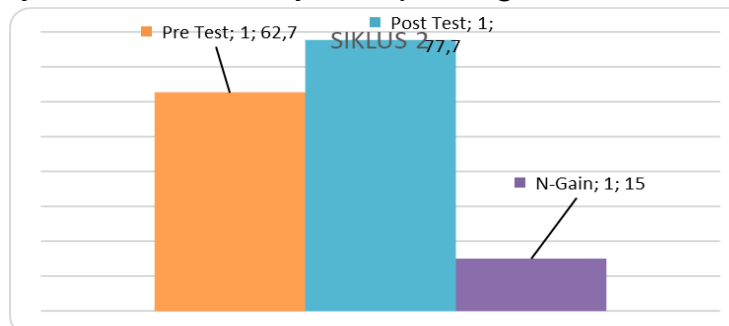

Gambar 2 Diagram Nilai Rata-Rata Pre Test dan Post Test Siklus II

Diagram di atas menunjukan nilai rata-rata pre test yang diperoleh siswa sebelum dilakukan tindakan (pra tindakan) mencapai nilai 62,7 dan setelah peneliti melakukan tindakan yaitu menerapkan model pembelajaran PCL, maka nilai rata-rata hasil belajar aspek kognitif siswa siklus II meningkat dengan $\mathrm{N}$-gain sebesar 15 yaitu menjadi 77,7 .

\section{Aktivitas Belajar Siswa}

Data hasil observasi terhadap aktivitas belajar siswa selama proses pembelajaran siklus ke-2 dapat dilihat pada tabel di bawah ini:

Tabel 4 Hasil Pengamatan Aktivitas Belajar Siswa Siklus II

\begin{tabular}{|l|l|l|l|l|}
\hline No. & Skor & Frekuensi & Persentase $(\%)$ & Kategori \\
\hline 1 & $<59$ & 1 & 4,55 & Kurang Sekali \\
\hline 2 & $60-69$ & 4 & 18,18 & Kurang \\
\hline 3 & $70-79$ & 6 & 27,27 & Cukup \\
\hline 4 & $80-89$ & 11 & 50 & Baik \\
\hline 5 & $90-100$ & & & Amat Baik \\
\hline
\end{tabular}

Data pada tabel di atas menunjukan bahwa aktivitas belajar siswa pada kegiatan belajar mengajar pada siklus kedua sudah termasuk kategori tinggi dengan perolehan skor rata-rata sebesar 77,13 . Aktivitas belajar siswa pada siklus ke-2 mengalami peningkatan $8,38 \%$ dari siklus ke-1. 


\section{Refleksi}

Setelah melakukan observasi, penulis melakukan refleksi untuk menilai seberapa jauh keberhasilan penelitian.

\section{Kegiatan Pembelajaran Siklus III Perencanaan}

Penulis membuat perencanaan tindakan yang akan dilaksanakan pada siklus pertama. Rencana yang dibuat adalah keseluruhan proses pembelajaran yang disesuaikan dengan tujuan meningkatkan hasil belajar dan aktivitas belajar siswa.

\section{Pelaksanaan}

Pelaksanaan pembelajaran siklus III dengan jumlah siswa yang hadir 22 orang. Pembelajaran pada siklus III ini membahas materi tentang memeriksa bahan makanan dengan teliti sesuai dengan prosedur perusahaan. Kegiatan pembelajaran siklus III ini diamati oleh observer.

\section{Hasil Belajar Siswa}

Hasil belajar yang dimaksud pada penelitian ini adalah hasil belajar berupa nilai pre test dan nilai post test. Hasil dari pre test dan post test siklus ketiga diperoleh sebagai berikut:

Tabel 5 Data Nilai Pre Test dan Post Test Siklus III

\begin{tabular}{|c|c|c|c|c|c|c|c|}
\hline \multirow[b]{2}{*}{$\begin{array}{l}N \\
0\end{array}$} & \multirow[b]{2}{*}{ Nilai } & \multicolumn{2}{|l|}{ Pretest } & \multicolumn{2}{|l|}{ Posttest } & \multirow{2}{*}{\multicolumn{2}{|c|}{ Keterangan }} \\
\hline & & $\begin{array}{l}\text { Frekuens } \\
\mathrm{i}\end{array}$ & $\begin{array}{l}\text { Persentase } \\
(\%)\end{array}$ & Frekuens & $\begin{array}{l}\text { Persentase } \\
(\%)\end{array}$ & & \\
\hline 1 & $\begin{array}{l}90 \leq \mathrm{Nk} \leq 10 \\
0\end{array}$ & 2 & 9,09 & 11 & 50 & \multirow{3}{*}{$\begin{array}{l}\text { Kompete } \\
n\end{array}$} & $\begin{array}{l}\text { Amat } \\
\text { Baik }\end{array}$ \\
\hline 2 & $80 \leq N k \leq 89$ & 2 & 9,09 & 8 & 36,36 & & Baik \\
\hline 3 & $70 \leq \mathrm{Nk} \leq 79$ & 9 & 40,91 & 3 & 13,64 & & Cukup \\
\hline \multirow[t]{4}{*}{4} & $0 \leq N k \leq 69$ & 9 & 40,91 & & & \\
\hline & Rata-Rata & \multicolumn{2}{|l|}{66,3} & \multicolumn{2}{|l|}{83,6} & \multirow{3}{*}{\multicolumn{2}{|c|}{ Belum Kompeten }} \\
\hline & N-Gain & \multicolumn{4}{|l|}{17,3} & & \\
\hline & Jumlah & 22 & 100 & 22 & 100 & & \\
\hline
\end{tabular}

Berdasarkan data hasil penelitian, yang diperoleh dari siklus III dapat ditunjukan bahwa nilai rata-rata pre test adalah 66,3. Setelah menerapkan model pembelajaran PCL, maka nilai rata-rata ketuntasan hasil belajar aspek kognitif siswa siklus III meningkat dengan $\mathrm{N}$-gain sebesar 17,3 dari nilai awal 66,3 yaitu menjadi 83,6. Rinciannya sebagai berikut: 11 orang $(50 \%)$ masuk kategori amat baik; 8 orang $(36,36 \%)$ masuk kategori baik, dan 3 orang $(13,64 \%)$ masuk kategori cukup.

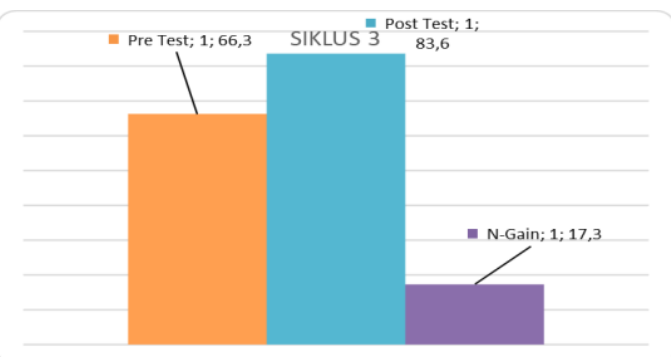

Gambar 3 Diagram Nilai Rata-Rata Pre Test dan Post Test Siklus III

Data di atas menunjukkan nilai rata-rata pre test yang diperoleh siswa sebelum dilakukan tindakan (pra tindakan) adalah 66,3 , dan setelah peneliti melakukan tindakan 
yaitu menerapkan model pembelajaran $\mathrm{PCL}$, maka nilai rata-rata hasil belajar aspek kognitif siswa siklus III meningkat dengan $\mathrm{N}$-gain 17,3 sebesar yaitu menjadi 83,6.

\section{Aktivitas Belajar Siswa}

Data hasil observasi terhadap aktivitas belajar siswa selama proses pembelajaran siklus ke-3 dapat dilihat pada tabel di bawah ini

Tabel 6 Hasil Pengamatan Aktivitas Belajar Siswa Siklus 3

\begin{tabular}{|l|l|l|l|l|}
\hline No. & Skor & Frekuensi & Persentase (\%) & Kategori \\
\hline 1 & $<59$ & & & Kurang Sekali \\
\hline 2 & $60-69$ & & & Kurang \\
\hline 3 & $70-79$ & & & Cukup \\
\hline 4 & $80-89$ & 17 & 77,27 & Baik \\
\hline 5 & $90-100$ & 5 & 22,73 & Amat Baik \\
\hline
\end{tabular}

Data pada tabel di atas menunjukkan bahwa aktivitas belajar siswa pada kegiatan belajar mengajar siklus ketiga termasuk pada kategori sangat tinggi dengan perolehan skor rata-rata sebesar atau 89,35. Aktivitas belajar siswa pada siklus 3 mengalami peningkatan sebesar $12,22 \%$ dari siklus ke-2.

\section{Refleksi}

Kegiatan refleksi penulis lakukan setelah kegiatan di kelas. Pada kegiatan ini, penulis melihat lembar observasi. Hasil refleksi ini penulis peroleh dari evaluasi kegiatan bersama observer dan guru mata pelajaran mengenai kegiatan yang terjadi saat proses pembelajaran. Setelah melakukan observasi, penulis melakukan refleksi untuk mengukur seberapa jauh keberhasilan pembelajaran. Hal yang dapat disimpulkan dari pelaksanaan siklus III: a. Peningkatan aktivitas siswa juga berpengaruh pada hasil belajar siswa yang di ukur melalui nilai pre-test dan post-test yang siklus ke siklus berikutnya terus mengalami kenaikan. Sehingga di akhir pembelajaran siklus ketiga ini rata-rata siswa dikategorikan kompeten dengan predikat amat baik. b. Berdasarkan hasil analisis pada siklus III, pada dasarnya proses pembelajaran telah menunjukan tahap-tahap penerapan model pembelajaran Problem Centered Learning dapat dilaksanakan cukup baik, dan dapat meningkatkan hasil belajar dan aktivitas belajar siswa pada materi memeriksa bahan makanan dengan teliti sesuai dengan prosedur perusahaan. Ada beberapa hal yang harus terus diperbaiki secara berkelanjutan. Guru juga harusterus memberikan bimbingan kepada siswa yang kurang aktif, sehingga guru benar- benar berperan sebagai fasilitator dalam kegiatan PBM.

\section{Pembahasan Hasil Penelitian}

Secara keseluruhan tahap-tahap pelaksanaan penerapan model pembelajaran Problem Centered Learning (PCL) yang dilakukan oleh peneliti berjalan dengan baik. Setiap siklus pembelajaran peneliti berusaha memperbaiki kekurangan yang ada sehingga tujuan pembelajaran yang telah direncanakan tercapai dengan cara melihat refleksi pembelajaran sebelumnya. Berdasarkan nilai indikator kinerja pada aspek kognitif (post test) sudah melebihi nilai rata-rata kelas $\geq 70,00$ dan peningkatan aktivitas siswa setiap siklusnya. Berikut ini adalah pembahasan hasil penelitian berdasarkan aspek yang dinilai. 
Hasil belajar siswa merupakan gabungan dari pengolahan data hasil belajar aspek kognitif. Hasil belajar siswa dari siklus I sampai siklus III didapat dari hasil tes dan lembar observasi, dapat dilihat pada gambar di bawah ini.

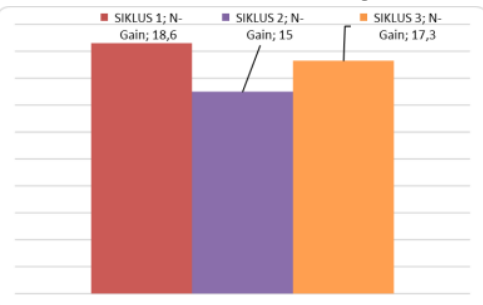

\section{Gambar 4 Diagram Perkembangan Hasil Belajar Siswa Tiap Siklus}

Gambar di atas menunjukan hasil rata-rata untuk N-gain siklus I memiliki prosentase 18,6, pada siklus II mengalami penurunan sebesar 3,6 menjadi 15, kemudian pada siklus III mengalami peningkatan 2,3 menjadi 17,3.

Peningkatan hasil belajar pada siklus I sampai siklus III cenderung mengalami peningkatan. Hal ini dikarenakan salah satu keunggulan PCL menurut Heru Hardani (2009) bahwa "PCL dapat meningkatkan hasil belajar siswa". Sejalan dengan itu Janulis P. Purba (2010:1) berpendapat bahwa "PCL merupakan salah satu variabel penting yang mempengaruhi hasil belajar siswa". Berdasarkan pemaparan di atas dapat disimpulkan bahwa model pembelajaran PCL dapat meningkatkan hasil belajar siswa sesuai dengan data yang penulis dapatkan selama penelitian berlangsung.

\section{Aktivitas Siswa}

Penilaian aktivitas siswa selama kegiatan pembelajaran Problem Centered Learning (PCL) dilihat dari lembar observasi aktivitas siswa yang diamati setiap siklus oleh guru (observer) dan teman peneliti (peer observer). Aktivitas siswa merupakan respon siswa terhadap pembelajaran yang diberikan fasilitator dengan aspek penilaian yang telah ditentukan sebelumnya. Untuk melihat gambaran kenaikan rata-rata aktivitas siswa pada setiap siklus dapat dilihat pada gambar diagram di bawah ini.

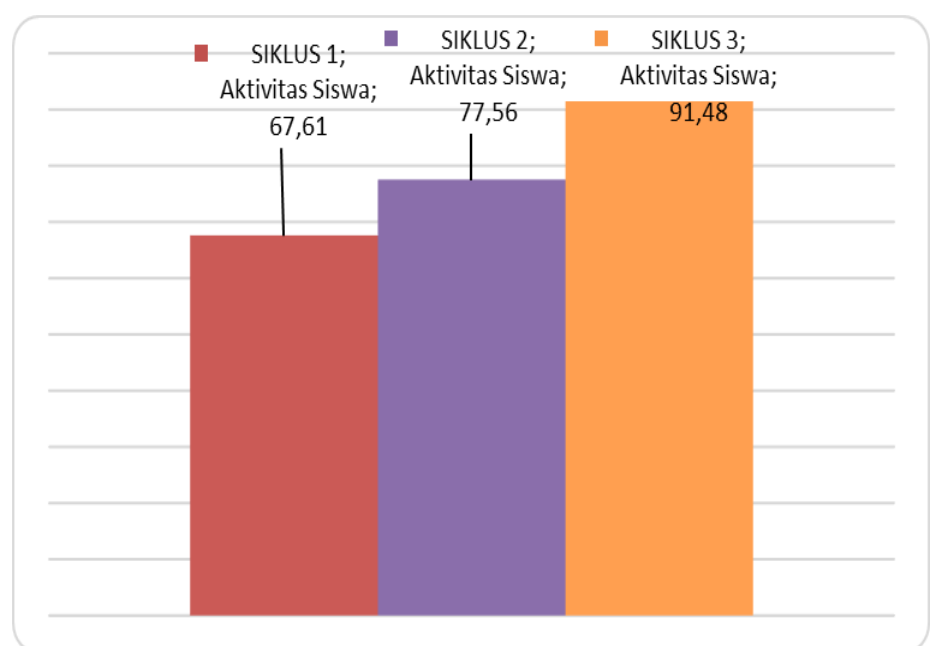

Gambar 5 Diagram Hasil Observasi Aktivitas Siswa pada Setiap Siklus

Diagram di atas menunjukkan hasil rata-rata untuk siklus I memiliki skor 67,61 (kategori tinggi) pada siklus II skor mengalami peningkatan sebesar 9,95 menjadi 77,56 (kategori sangat tinggi), kemudian pada siklus III skor mengalami peningkatan 13,92 menjadi 91,48 (kategori sangat tinggi). Model pembelajaran PCL memberikan 
hasil positif terhadap kegiatan belajar mengajar karena dapat meningkatkan aktivitas siswa, sesuai dengan data yang didapat dari hasil observasi. Peningkatan aktivitas belajar siswa ini terkait dengan karakteristik model pembelajaran PCL yaitu aktivitas pembelajaran yang tinggi, memecahkan permasalahan dan belajar mandiri dapat meningkatkan aktivitas siswa, setiap langkah yang diberikan menuntut keaktifan belajar siswa. Hal ini sesuai dengan pendapat Sudjana (2009: 28) bahwa "model pembelajaran PCL mengandung aktivitas pembelajaran yang cukup tinggi". Sejalan dengan itu Sanjaya (2006: 219) menyatakan bahwa "salah satu keunggulan dari PCL dapat meningkatkan aktivitas pembelajaran siswa".

\section{KESIMPULAN}

Tujuan dan pembahasan hasil penelitian yang telah dilakukan, maka diperoleh kesimpulan; 1) Hasil belajar siswa meningkat dari siklus I sampai III setelah dilakukan tindakan menggunakan model pembelajaran PCL. Hasil belajar pada siklus I termasuk ke dalam kategori kompeten dengan predikat cukup. Siklus II mengalami peningkatan dari siklus I menjadi kategori kompeten dengan predikat baik. Siklus III pun lebih baik dari siklus II karena hasil belajar siswa meningkat menjadi kategori kompeten dengan predikat amat baik. 2) Aktivitas belajar siswa meningkat dari siklus I sampai III setelah dilakukan tindakan menggunakan model pembelajaran PCL. Aktivitas siswa pada siklus I termasuk ke dalam kategori sedang, kemudian mengalami peningkatan menjadi kategori tinggi pada siklus II, dan meningkat menjadi kategori sangat tinggi pada siklus III.

Berdasarkan hasil kesimpulan pada penelitian ini dan untuk meningkatkan penerapan model Problem Centered Learning (PCL) pada standar kompetensi melakukan penyimpanan barang, peneliti menyampaikan saran dan rekomendasi sebagai berikut: 1) Bagi guru, pembelajaran dengan model pembelajaran Problem Centered Learning (PCL) dapat dijadikan alternatif pembelajaran yang dapat digunakan, karena dengan pembelajaran ini dapat meningkatkan aktivitas dan hasil belajar siswa. 2) Bagi sekolah, mengenai model pembelajaran Problem Centered Learning ( $\mathrm{PCL}$ ) di sekolah dapat terus dikembangkan. Penerapan pembelajaran Problem Centered Learning (PCL) dapat diterapkan oleh guru pada standar kompetensi yang berbeda sebagai salah satu alternatif dalam inovasi pembelajaran. 3) Untuk meningkatkan kegiatan pembelajaran di kelas hendaknya kebutuhan peralatan dan sumber-sumber belajar dapat dilengkapi, khususnya untuk menunjang kegiatan pembelajaran sesuai dengan perkembangan kebutuhan dunia usaha saat ini.

\section{DAFTAR RUJUKAN}

Arikunto,S. 2002. Peneletian Tindakan Kelas. Jakarta : Bumi Aksara.

Arikunto, Suharsimi. 2011. Prosedur Penelitian: Suatu Pendekatan Praktik. Edisi.

Arsyad, Azhar. 2009. Media Pembelajaran. Jakarta: Rajawali Press

Hafriani.(2004).Mengembangkan Kemampuan Pemecahan Masalah Matematik Mahasiswa Melalui Problem Centered Learning.Tesis Pps Upi Bandung : Tidak Diterbitkan.

Suwardi.(2009).Perbandingan Problem Centered Learning (Pcl) Dengan Metode Ekspositori Terhadap Prestasi Belajar Siswa Pada Mata Diklat Menganalisis Rangkaian Listrik Dan Elektronika.Skripsi JPTE FPTK UPI Bandung : Tidak Diterbitkan.

Sanjaya, Wina. 2006. Strategi Pembelajaran Berorientasi Standart Proses Pendidikan. Jakarta: Kencana Prenada Media 
Sadirman, A M.(2011). Interaksi Dan Motivasi Belajar Mengajar. Jakarta : PT. Raja Grafindo Persada.

Suwardi.(2009). Perbandingan Problem Centered Learning (PCl) Dengan Metode Ekspositori Terhadap Prestasi Belajar Siswa Pada Mata Diklat Menganalisis Rangkaian Listrik Dan Elektronika.Skripsi JPTE FPTK UPI Bandung : Tidak Diterbitkan

Sudjana, Nana. 2010. Penelitian Hasil Proses Belajar Mengajar. Bandung: PT. Remaja Rosda Karya.

Wheatley, G(2001). The Problem Centered Classroom.[Online]. Tersedia ; Http://Www.Learn.Org [10 Juni 2012]. 